\title{
ANALISIS MODEL TRANSSHIPMENT DALAM PROSES DISTRIBUSI PRODUK SEMEN DI CV BANGUN KREASI ABADI
}

\author{
Joshua Gianfranco $^{1 *}$, Tasya Mursalina ${ }^{1}$, Muchammad Fauzi ${ }^{1}$ \\ ${ }^{1}$ Program Studi Teknik Industri Fakultas Teknik \\ Universitas Widyatama \\ Jln. Cikutra No. 204, Bandung, 40227, Indonesia \\ *Penulis Korespondensi: joshua.gianfranco@widyatama.ac.id
}

\begin{abstract}
CV. Bangun Kreasi Abadi is one of the distributors working with PT. Jui Shin Indonesia in marketing and distributing Garuda cement products to several regions in West Java, especially the city of Bandung. In the distribution process, CV Bangun Kreasi Abadi does not send its cement products directly to consumers, but $C V$. Bangun Kreasi Abadi uses two warehouses as transit points for the delivery of cement products for several regions. The transshipment method has several problems because in the distribution process, products are not sent directly to consumers but must passthrough several transit points first. This will result in large costs because the deliveryprocess will be twice as long and will also result in a longer lead time. This study aims to determine the optimal allocation of Garuda cement distribution to produce minimum transportation costs from distributors to warehouses and from warehousesto service points (retailers) using the Transshipment method with the help of Lingo Solver Software. The result of transportation costs from distributors to warehouses isRp. 25,655,900 and transportation costs from warehouses to retailers of Rp. 26, 140,220, the total cost of Garuda cement distribution is Rp. 51,796,120.
\end{abstract}

Keywords: Cement, Transshipment, Warehouse, Lingo

\section{Pendahuluan}

CV. Bangun Kreasi Abadi merupakan distributor dari PT Jui Shin Indonesia untuk mendistribusikan dan memasarkan produk semen Garudauntuk retailer di wilayah Kota Bandung. $\mathrm{CV}$. Bangun Kreasi Abadi memiliki dua gudang yang berlokasi di Moh.Toha dan Gedebage. Fungsi dari kedua gudang ini yaitu untuk membantu proses pendistribusian semen Garuda untuk titik tujuan (retailer) yang tersebar di wilayah kota Bandung. Masing-masing gudang tersebut memiliki kapasitas dan kebutuhan masing-masing dalam proses pendistribusian ke titik tujuan.

Kebutuhan semen di masingmasing titik tujuan (retailer) tentu bervariatif, biaya distribusi pun berbedabeda begitu juga dengan kapasitas gudang yang digunakan untuk menyimpan produk sebelum diantarkan ke konsumen. Kapasitas di gudang Moh. Toha yaitu 10.240 sak per 2 bulan, dan untuk kapasitas gudang Gedebage yaitu 15.360 sak per 2 bulan, maka total kapasitas dari 2 gudang ini yaitu 25.600 sak untuk memenuhi kebutuhan produk semen ke retailer. Sedangkan kebutuhan produk semen untuk semua titik tujuan (retailer) yaitu 28.967 sak per 2 bulan, dengan ongkos total biaya pendistribusian dari kedua gudang ke semua titik tujuan (retailer) dengan menggunakan metode Vogel Aproximation Method sebesar Rp. 26,193,119(Christian, 2019).

Pada penelitian sebelumnya (Christian, 2019) menunjukkan bahwa kapasitas gudang yang tersedia tidak bisa memenuhi kebutuhan produk semen 
untuk semua titik tujuan karena kebutuhan semen untuk semua titik tujuan (retailer) lebih besar daripada kapasitas kedua gudang yang tersedia. Sehingga dalam penyelesaiannya perlu penggunaan model transportasi yang berhubungan dengan transit.

Penelitian ini merupakan pengembangan dari penelitian sebelumnya yang menggunakan model riset operasi Vogel Aproximation Method (VAM) sebagai metode yang digunakan untuk mencari ongkos total biaya distribusi semen di CV. Bangun Kreasi Abadi, dikembangkan dengan menggunakan model Transshipment guna menyelesaikan masalah transit, alokasi kebutuhan, kapasitas gudang dan perhitungan ongkos total biaya distribusi semen di CV. Bangun Kreasi Abadi agar menjadi seminimum mungkin.

Pada metode transshipment, biaya distribusi total dihitung dari biaya awal pendistribusian CV. Bangun Kreasi Abadi ke gudang, lalu biaya distribusi dari gudang menuju titik tujuan (retailer). Tujuan dilakukannya penelitian ini yaitu untuk menentukan alokasi distibusi semen Garuda yang optimal untuk menghasilkan biaya transportasi minimum dari distributor ke gudang dan dari gudang ke titik tujuan (retailer). Penyelesaian masalah transshipment di atas, dapat diselesaikan dengan menggunakan bantuan Lingo solver software.

\section{Tinjauan Pustaka}

Beberapa penelitian serupa pernah dilakukan oleh beberapa peneliti sebelumnya diantaranya Hartono (Hartono, 2017) pada 2017 telah melakukan penelitian di kabupaten Pasuruan tentang optimalisasi biaya transportasi dengan model transshipment dalam pendistribusian pupuk bersubsidi pada CV. Gilang Perkasa Pasuruan. Hasil analisis menunjukkan bahwa jalur distribusi yang dilakukan perusahaan belum maksimal sehingga biaya yang dikeluarkan pun cukup besar. Hasil analisa memberikan hasil bahwa biaya yang lebih efisien yaitu menggunakan model transshipment dibandingkan dengan proses distribusi yang dilakukan perusahaan pada periode sebelumnya. Total biaya distribusi dari hasil analisis memiliki selisih sebesar $48 \%$. Penelitian selanjutnya oleh Muhammad Farid Syafi'I (Syafi'i, 2015) pada tahun 2014, dalam menganalisis jalur pendistribusian dan biaya distribusi pada proses pendistribusian pupuk Petrokimia Gresik, menggunakan model Transshipment dan metode linear programming. Hasil analisis menunjukan penghematan terhadap biaya distribusi sebesar Rp. 148,610,400 per tahun. Lalu penelitian selanjutnya dilakukan oleh Irine Silviani(Silviani 2012) pada tahun 2012 yang melakukan penelitian optimalisasi pendistribusian pupuk urea bersubsidi. Hasil analisis dengan menggunakan linear programming dan model transportasi menghasilkan penghematan biaya distribusi sebesar Rp. 32,585,000 per tahun. Menurut pendapat Siswanto (Siswanto, 2006) dalam matematik untuk menyelesaikan masalah transit dapat diselesaikan dengan model riset operasi yaitu Transshipment.

Transshipment merupakan masalah model transportasi, dalam mengirim barang dari tempat produksi ke tempat permintaan tidak dapat dilakukan secara langsung satu arah. Model transshipment merupakan model transportasi yang memungkinkan dilakukannya pengiriman komoditas secara tidak langsung, barang dari suatu sumber dapat berada pada sumber lain atau tujuan lain sebelum mencapai tempat permintaan. Penyatuan pada proses pendistribusian telah banyak dipergunakan yang memiliki tujuan untuk mengurangi biaya dan meningkatkan layanan kepada konsumen sehingga dikembangkan proses pendistribusian lanjutannya yaitu pendistribusian dengan model transshipment. Model transshipment merupakan masalah model transportasi yang dimana sebagian atau seluruh barang yang dibawa dari sumber tidak 
langsung dikirim ke tujuan namun terlebih dahulu melakukan transit. Selanjutnya, mengubah tabel transshipment ke model transportasi umum(Muhamad, 2020).

Distribusi merupakan salah satu bagian dari aktivitas perusahaan yang dianggap sangat penting. Fungsi dari distribusi tersebut yaitu penyaluran hasil produksi perusahaan ke konsumen. Namun, nyatanya proses distribusi ini mempunyai hambatan yang disebabkan karena adanya masalah dalam sistem transportasi. Rute pada proses pengiriman produk menjadi salah satu faktor penentu dalam proses minimalisasi biaya transportasi, penentuan jalur yang terpendek menuju agen dapat dilakukan oleh perusahaan guna menentukan jarak yang ditempuh. Faktor utama dalam penentuan biaya yaitu jarak, minimalisasibiaya dan waktu akan didapatkanperusahaan apabila jarak yan ditempuh semakin kecil(Aida and Rahmanda, 2020).

Model transshipment dapat digunakan perusahaan sebagai caradalam proses minimalisasi biaya yang dikeluarkan oleh perusahaan dan peningkatan pelayanan kepada konsumen (Muhammad et al. 2013).

\section{Metodologi Penelitian \\ Transportasi}

Model transportasi dan juga distribusi merupakan bagian yang sangat vital dalam mendukung jalannyaaktivitas keberhasilan mempengaruhi pendistribusian. Keefektifan penyaluran produk ke konsumen tentunya didukung dengan proses distribusi yang baik. Meningkatnya kebutuhan dari komoditi produk di suatu wilayah menjadi masalah dalam pengembangan perusahaan karena adanya masalah proses transportasi. Permasalahan pada proses transportasi timbul apabila di perusahaan melakukan usaha dalam proses pengiriman suatu komoditi ke tujuan dengan tujuan meminimumkan biaya (Ratnasari et al. 2019).
Masalah transportasi secara umum berhubungan dengan proses pendistribusian produk dari suatu sumber (produsen) menuju beberapa tujuan tertentu (konsumen) sesuai dengan permintaan, dengan harapan biaya transportasi yang dikeluarkan seminimal mungkin. Model transportasi dapat diselesaikan dengan menggunakan program linear, yang padaa dasarnya berhubungan dengan pengaturan proses distribusi yang optimal terhadap suatu produk dengan jenis yang sama (homogen), dari beberapa lokasi atau sumber asal menuju ke beberapa lokasi atau tempat tujuan tertentu. Titik asal atau sumber dapat berupa pabrik,gudang, agen, atau lainnya di mana yangdimaksud tujuan adalah titik-titik pelayanan penerimaan produk tersebut(Margaretta, 2018).

Menurut Taha, dalam arti sederhana, model transportasi berusaha menentukan sebuah jalur transportasi sebuah barang dari sejumlah sumber ke sebuah tujuan. Data dalam model ini mencakup:

1. Tingkat penawaran di setiap sumber dan jumlah permintaan di setiap tujuan.

2. Biaya transportasi per unit barang dari setiap sumber ke setiap tujuan.

Tujuan dari model transportasi yaitu untuk menentukan jumlah yang harus dikirimkan dari setiap sumber ke setiap tujuan sedemikian rupa sehingga biaya transportasi total diminimumkan. Sebuah tujuan dapat menerima permintaannya dari lebih satu sumber atau hanya satu sumber(Ord and Taha 2014).

Hal-hal yang perlu diketahui dalam penggunaan model transportasi:

1. Titik asal dan kapasitas atau pasokan pada setiap periode.

2. Titik tujuan dan permintaan pada setiap periode.

3. Biaya pengiriman satu unit dari setiap titik asal ke titik tujuan. 


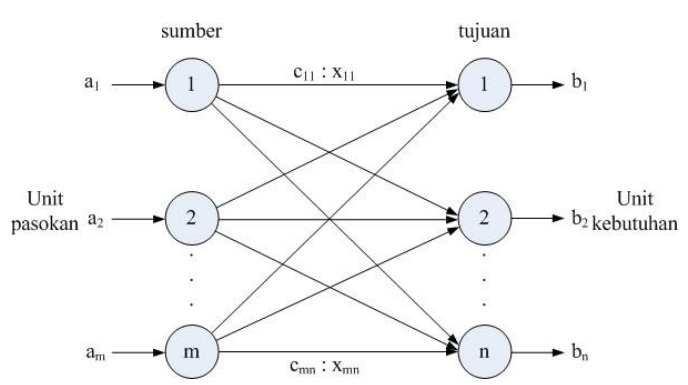

Gambar 1. Metode transportasi

Masalah transportasi dapat dilihat di gambar 1. Ada titik sumber dan titik tujuan setiap sumber atau tujuan ditunjukkan dengan sebuah node. Sumber dan tujuan dihubungkan dengan panah. Panah $(m, n)$ yang menggabungkan sumber $m$ ke tujuan $n$ membawa dua informasi: biaya transportasi per unit, $c_{m n}$, dan jumlah yang dikirim, $x_{m n}$. Jumlah pasokan pada sumber adalah $a_{m}$ dan jumlah kebutuhan tujuan di $n$ adalah $b_{n}$. Tujuan model menentukan $x_{m n}$ yang tidak diketahui yang akan meminimalkan total biaya transportasi yang memenuhi batas sumber dari pasokan dan kebutuhan di tujuan(Anon 2011).

\section{Transshipment}

Transshipment merupakan metode yang berkembang dari permasalahan transportasi yang meliputi mengenai minimalisasi biaya distribusi barang dari suatu sumber ke tujuan secara tidak langsung, dimana harus mengalami dua atau beberapa proses pendistribusian sebelum barang sampai ke tempat tujuan(Aida and Rahmanda 2020).

Minimasi biaya distribusi dapat diselesaikan dengan metode transshipment, dengan variabel keputusan sebagai berikut(Bella et al. 2020):

$\mathrm{Xi}=$ Vendor

$\mathrm{Xj}=$ Manufacture

$\mathrm{Xk}=$ Distribution Center

Batasan masalah yang dimiliki sebagai berikut:

$$
\begin{aligned}
& { }_{\mathrm{n}}^{\text {Sumber: }}{ }_{\mathrm{n}}{ }_{\mathrm{n}} \\
& \sum \sum \mathrm{Xij}+\sum \sum \mathrm{Xjk} \leq \mathrm{Di}
\end{aligned}
$$

$$
\begin{aligned}
& \sum \sum \mathrm{Xjk}=\mathrm{Dk} \\
& \mathrm{j}=1 \mathrm{k}=1 \\
& \text { Implisit: } X i j, X j k \geq 0 \text { (3) } \\
& \text { Fungsi tujuan minimasi: } \\
& Z_{\text {min }}=\sum^{n} X_{i j} \cdot C_{i j}+\sum X_{j k} \cdot C_{j k}
\end{aligned}
$$

$$
\mathrm{i}=1 \quad \mathrm{j}=1
$$

Cara penyelesaian dalam perubahan masalah transshipment ke masalah transportasi meliputi beberapa bagian,:

1. Menyeimbangkan tabel. Teiliti apakah jumlah persediaan barang (node bertanda + ) sama

2. dengan jumlah permintaan (node bertanda - ). Apabila table belum seimbang, perlu ditambahkan dummy.

3. Tentukan titik sumber, titik tujuan, dan titik perantara.

4. Tentukan jumlah persediaan dan permintaan tiap titik.

5. Tentukan biaya pengiriman.

\section{Vogel Aproximation Method (VAM)}

Vogel Aproximation Method merupakan salah satu metode optimasi dalam penyelesaian kasus transportasi dengan cara yang mudah dan cepat. Namun demikian, penyelesaian yang diperoleh terkadang belum optimal, sehingga perlu dioptimalisasi. Hasil awal metode VAM masih bisa dioptimalkan dengan metode optimasi lanjutan, contohnya metode MODI.

Langkah-langkah metode Vogel Aproximation Method sebagai berikut(Siswanto 2006):

1. Tentukan perbedaan dua biaya terkecil pada setiap baris dan setiap kolom pada tabel.

2. Pilih nilai perbedaan terbesar, dimana baris atau kolom yang mempunyai nilai perbedaan terbesar merupakan baris atau kolom awal pengisian.

3. Kemudian pilih sel pada baris atau kolom yang terpilih

mempunyai biaya terendah di 


$$
i=1 \quad j=1 \quad j=1 \quad k=1
$$

mana sel ini akan dilakukan pengisian. 
4. Berdasarkan baris dan kolom yang tersisa, ulangi langkah satu untuk baris atau kolom yang belum terisi, lalu lanjutkan ke point tiga dan empat.

\section{Lingo Solver Software}

Permasalahan transportasi yang bervaraisi tentunya perlu pengerjaan yang teliti dan cepat, program komputer yang dapat membantu proses penyelesaian masalah ini diantaranya yaitu Lingo. Perhitungan yang sangat cepat dengan program komputer ini akan sangat membantu untuk menyelesaikan model dengan kendala yang cukup banyak.

Efisiensi waktu dalam pemecahan masalah suatu perusahaan sangat diperhatikan. Diperlukannyasuatu tools yang efektif, praktis dan tentunya efisien dalam membantu proses penyelesaian masalah tersebut (Bella et al. 2020). Bantuan komputer dapat mempermudah penyelesaian masalah. Lindo, Lingo Solver dan WinQSB adalah beberapa aplikasi komputer yang dapat digunakan untuk penyelesaian masalah tersebut. WinQSB adalah program komputer yang menggunakan algoritma problem solving untuk ilmu manajemen dan riset operasi. Program Lingo untuk menyelesaikan masalah transshipment.

Metode yang digunakan dalam penelitian ini yaitu menggunakan metode Transshipment dengan bantuan Lingo Solver. Adapun langkah-langkah dalam melakukan penelitian ini yaitu identifikasi dan perumusan masalah, studi literatur, pengumpulan data, pengolahan data dan kesimpulan. Alur penelitian secara lengkap dapat dilihat pada gambar 2.

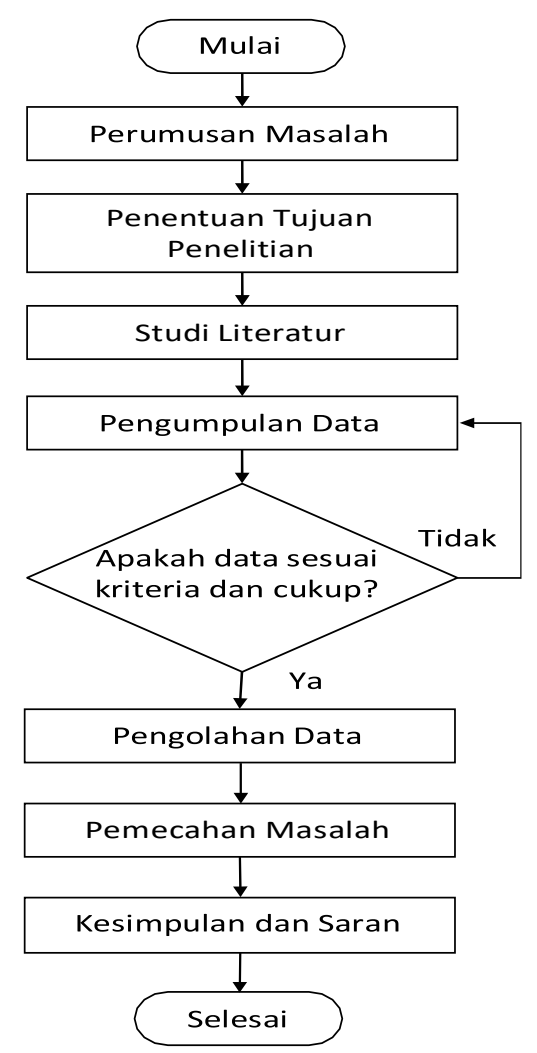

Gambar 2. Alur Metode Penelitian

\section{Hasil dan Pembahasan}

Data yang diperoleh merupakan data sekunder yang diambil dari penelitian sebelumnya. Proses pengiriman produk semen Garuda untuk daerah Bandung dipasarkan melalui distributor CV.Bangun Kreasi Abadi, yang memiliki dua gudang berlokasi di Gedebage dan Moh.Toha. Selanjutnya didistribusikan kepada masing-masing retailer CV.Bangun Kreasi Abadi berjumlah 36. Struktur jaringan distribusi CV.Bangun Kreasi Abadi ditunjukkan pada Gambar 3:

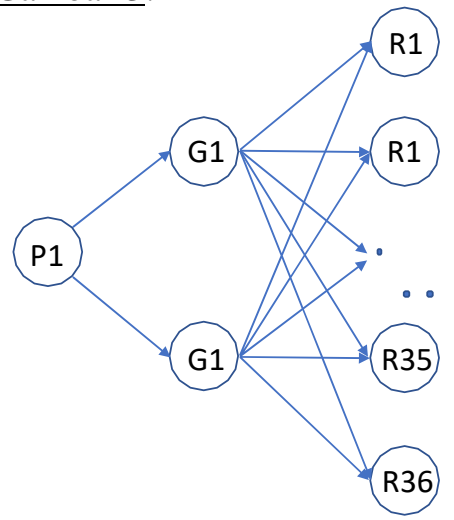

Gambar 3. Pendistribusian Semen Garuda CV.Bangun Kreasi Abadi 
Data yang digunakan adalah kapasitas distributor dan gudang, permintaan setiap retailer, biaya pengiriman dari distributor ke gudang serta biaya pengiriman dari gudang ke retailer CV. Bangun Kreasi Abadi.

Data kapasitas distributor dan gudang seperti yang ditunjukkan pada Tabel 1.

Tabel 1. Kapasitas Distributor dan Gudang

\begin{tabular}{cll}
\hline Titik & Kode & $\begin{array}{l}\text { Kapasitas } \\
\text { (Sak/2 } \\
\text { bulan) }\end{array}$ \\
\cline { 3 - 3 } Distributor & (P1) & 25,600 \\
Gudang Gedebage & (G1) & 10,240 \\
Gudang Moh. Toha & (G2) & 15,360 \\
\hline
\end{tabular}

Semen yang telah sampai digudang kemudian didistribusikan ke 36 retailer. Untuk data permintaan semen setiap retailer ditunjukkan pada tabel 2.

Tabel 2. Data Permintaan Januari-

\begin{tabular}{llc}
\multicolumn{3}{c}{ Rebruari 2019 } \\
\hline RB 99 & Kode & $\begin{array}{c}\text { Permintaan } \\
\text { (Sak)/2bulan }\end{array}$ \\
\hline Amjaya & (R1) & 5,216 \\
Babakan Jaya & (R2) & 489 \\
BP.Bhakti & (R4) & 488 \\
BP.Budi & (R5) & 160 \\
BP.Budianto & (R6) & 160 \\
BP.Dayat & (R7) & 100 \\
Buana & (R8) & 816 \\
Pembangunan & & \\
& & \\
Buana & (R9) & 204 \\
Cicalengka & & \\
Daya Utama & (R10) & 326 \\
Djamuju & (R11) & 651 \\
Garuda & (R12) & 500 \\
Karya Elnisi & (R13) & 304 \\
Manunggal & & \\
Hujang Wangi & (R14) & 2,119 \\
TB Ibu 3 & (R15) & 1,956 \\
Istana & (R16) & 1,467 \\
Rancamanyar & (R17) & 815 \\
Jaya Subur 1 & (R17)
\end{tabular}

\begin{tabular}{|c|c|c|}
\hline Retailer & Kode & $\begin{array}{c}\text { Permintaan } \\
\text { (Sak)/2bulan }\end{array}$ \\
\hline Mega Asri & (R18) & 640 \\
\hline TB Mekar Jaya & (R19) & 815 \\
\hline Mirah Jaya & (R20) & 1,428 \\
\hline $\begin{array}{ll}\text { Mitra } & \text { Elnisi } \\
\text { Selaras } & \end{array}$ & (R21) & 160 \\
\hline MR.Kwang & (R22) & 380 \\
\hline CV.Aicon & (R23) & 1,224 \\
\hline Mulya Jaya & (R24) & 816 \\
\hline Mustika Sari & (R25) & 163 \\
\hline Nensin & (R26) & 160 \\
\hline $\begin{array}{l}\text { Nuansa } \\
\text { Alumunium }\end{array}$ & (R27) & 204 \\
\hline $\begin{array}{l}\text { Putra Pribumi } \\
\text { Kusen }\end{array}$ & (R28) & 652 \\
\hline $\begin{array}{ll}\text { TB } & \text { Prima } \\
\text { Utama } & \end{array}$ & (R29) & 408 \\
\hline Pribumi Jaya & (R30) & 120 \\
\hline $\begin{array}{l}\text { PT Dwipuri } \\
\text { Abadi }\end{array}$ & (R31) & 320 \\
\hline Rossi Kusen & (R32) & 163 \\
\hline TB Sahabat & (R33) & 2,765 \\
\hline BP Sonny & (R34) & 480 \\
\hline SS Jaya & (R35) & 978 \\
\hline $\begin{array}{l}\text { Sinar Terang } \\
\text { Abadi }\end{array}$ & (R36) & 160 \\
\hline Total & & 28,967 \\
\hline
\end{tabular}

Biaya distribusi dari distributor ke setiap gudang ditunjukkan pada tabel 3 .

Tabel 3. Biaya distribusi dari distributor ke setiap gudang

\begin{tabular}{lcl}
\hline \multicolumn{2}{c}{ ke setiap gudang } \\
Titik Tujuan & Kode & $\begin{array}{l}\text { Biaya } \\
\text { distribu } \\
\text { si(Rp/sa } \\
\text { k) }\end{array}$ \\
\cline { 3 - 3 } Gudang Gedebage & $(\mathrm{G} 1)$ & 1,022 \\
Gudang Moh. Toha & (G2) & 997 \\
\hline
\end{tabular}

Biaya distribusi dari setiap gudang ke setiap tujuan ditunjukkan pada tabel 4. 
Tabel 4. Biaya distribusi dari setiap gudang ke setiap tujuan

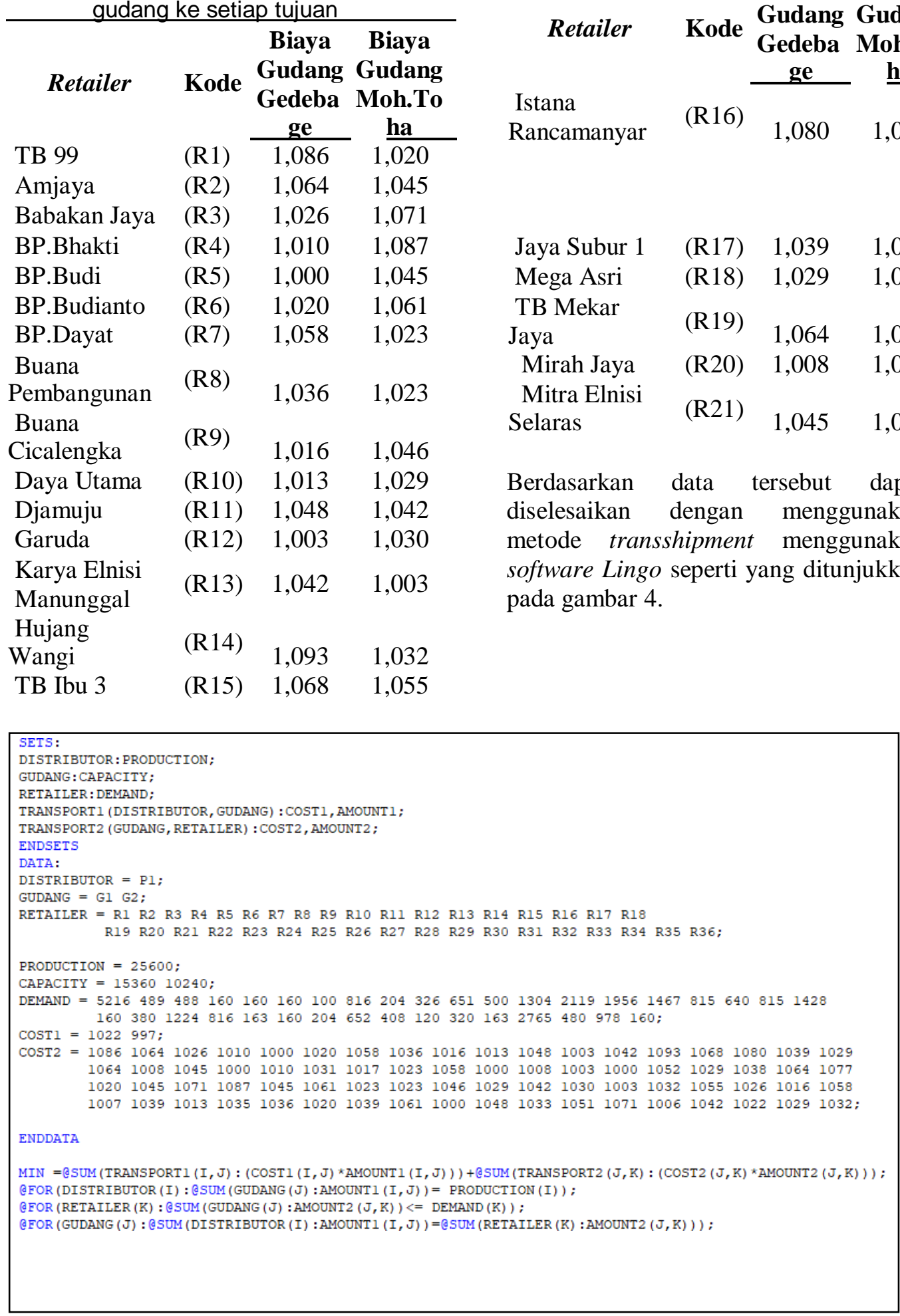

Gambar 4. Model Matematika Transshipment pada Lingo 


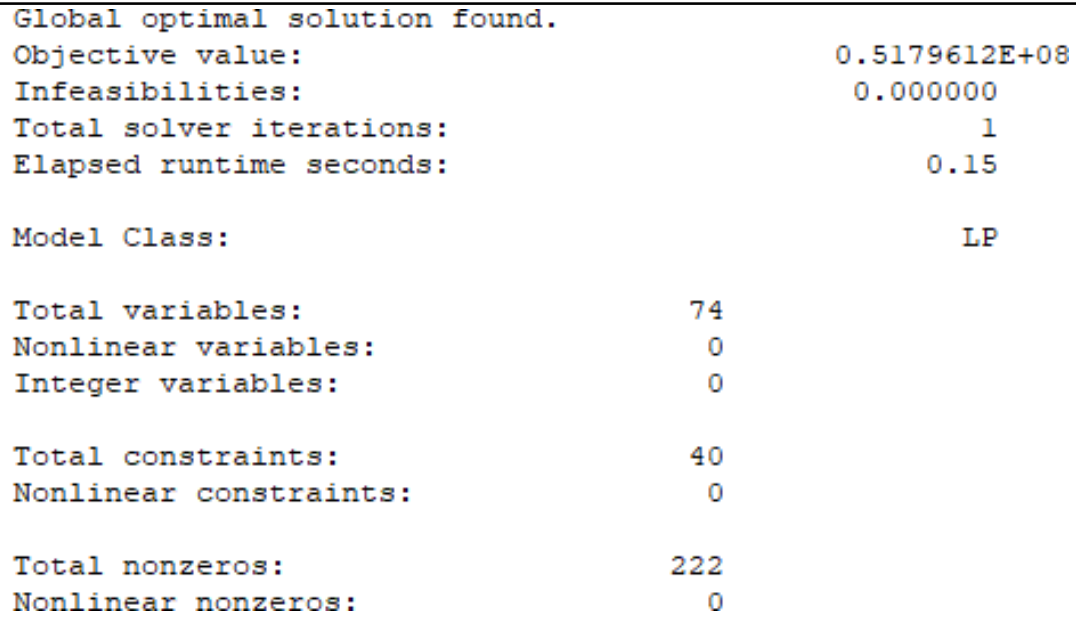

$0.5179612 \mathrm{E}+08$

0.000000

1

0.15

LP

74

0

40

0

222

0

Gambar 5. Hasil Penyelesaian Model Matematika Transshipment pada Lingo

Berdasarkan gambar 5 menunjukkan bahwa hasil:

1. Objective value merupakan nilai minimal total biaya pengiriman pada penelitian ini yaitu sebesar Rp.51.796.120.

2. Total variabel sebanyak 74 meliputi variabel-variabel yang menentukan jumlah pengiriman pada jaringan distribusi tersebut.

3. Total Batasan (constrain) sebayak 40 meliputi jumlah pengiriman dari distributor ke gudang tidak melebihi jumlah kapasitas distributor, jumlah pengiriman dari gudang ke retailer sama dengan permintaan retailer, dan jumlah persediaan di gudang sama dengan jumlah permintaan retailer juga sama dengan jumlah kapasitas distributor.

Alokasi distribusi dari distributor ke setiap gudang dan dari setiap gudang ke setiap retailer ditunjukkan pada tabel 5 berikut :

Tabel 5. Total biaya pengiriman pada CV.Bangun Kreasi Abadi

\begin{tabular}{ccccc}
\hline Dari & Ke & $\begin{array}{c}\text { Jumlah } \\
\text { (sak) }\end{array}$ & $\begin{array}{c}\text { Biaya } \\
\text { Distribusi } \\
\text { (sak) }\end{array}$ & $\begin{array}{c}\text { Total Biaya } \\
\text { Distribusi }\end{array}$ \\
\hline P1 & G1 & 5,308 & 1,022 & $5,424,776$ \\
P1 & G2 & 20,292 & 997 & $20,231,124$ \\
\hline G2 & R1 & 5,216 & 1,020 & $5,320,320$ \\
G2 & R2 & 366 & 1,045 & 382,470 \\
G1 & R3 & - & - & - \\
G1 & R4 & 160 & 1,010 & 161,600 \\
G1 & R5 & 160 & 1,000 & 160,000 \\
G1 & R6 & 160 & 1,020 & 163,200 \\
G2 & R7 & 100 & 1,023 & 102,300 \\
G2 & R8 & 816 & 1,023 & 834,768 \\
G1 & R9 & 204 & 1,016 & 207,264 \\
G2 & R10 & 326 & 1,029 & 335,454 \\
G2 & R11 & 651 & 1,042 & 678,342 \\
G1 & R12 & 500 & 1,003 & 501,500 \\
G2 & R13 & 1,304 & 1,003 & $1,307,912$
\end{tabular}




\begin{tabular}{|c|c|c|c|c|}
\hline Dari & $\mathbf{K e}$ & $\begin{array}{c}\text { Jumlah } \\
\text { (sak) }\end{array}$ & $\begin{array}{c}\text { Biaya } \\
\text { Distribusi } \\
\text { (sak) }\end{array}$ & $\begin{array}{l}\text { Total Biaya } \\
\text { Distribusi }\end{array}$ \\
\hline G2 & R14 & 2,119 & 1,032 & $2,186,808$ \\
\hline G2 & R15 & - & - & - \\
\hline G2 & R16 & 1,467 & 1,026 & $1,505,142$ \\
\hline G2 & R17 & 815 & 1,016 & 828,040 \\
\hline G1 & R18 & - & - & - \\
\hline G2 & R19 & 815 & 1,007 & 820,705 \\
\hline G1 & R20 & 1,428 & 1,008 & $1,439,424$ \\
\hline G2 & R21 & 160 & 1,013 & 162,080 \\
\hline G1 & R22 & 380 & 1,000 & 380,000 \\
\hline G1 & R23 & 1,224 & 1,010 & $1,236,240$ \\
\hline G2 & $\mathrm{R} 24$ & 816 & 1,020 & 832,320 \\
\hline G2 & R25 & 163 & 1,039 & 169,357 \\
\hline G1 & R26 & - & - & - \\
\hline G2 & R27 & 204 & 1,000 & 204,000 \\
\hline G1 & R28 & 652 & 1,000 & 652,000 \\
\hline G2 & R29 & 408 & 1,033 & 421,464 \\
\hline G1 & R30 & 120 & 1,003 & 120,360 \\
\hline G1 & R31 & 320 & 1,000 & 320,000 \\
\hline $\mathrm{G} 2$ & R32 & 163 & 1,006 & 163,978 \\
\hline $\mathrm{G} 2$ & R33 & 2,765 & 1,042 & $2,881,130$ \\
\hline G2 & R34 & 480 & 1,022 & 490,560 \\
\hline G2 & R35 & 978 & 1,029 & $1,006,362$ \\
\hline G2 & R36 & 160 & 1,032 & 165,120 \\
\hline \multicolumn{4}{|c|}{$\begin{array}{l}\text { Total Biaya pengiriman dari distributor } \\
\text { ke gudang }\end{array}$} & $25,655,900$ \\
\hline \multicolumn{4}{|c|}{$\begin{array}{l}\text { Total biaya pengiriman dari gudang ke } \\
\text { retailer }\end{array}$} & $26,140,220$ \\
\hline \multicolumn{4}{|c|}{ Total Biaya pengiriman } & $51,796,120$ \\
\hline
\end{tabular}

Total biaya pengiriman dari gudang ke retailer pada penelitian sebelumnya (Christian, 2019) menggunakan metode VAM sebesar Rp. 26,193,119 sedangkan pada penelitian ini menggunakan model transshipment dan menggunakan bantuan software lingo ongkos total pengiriman dari gudang ke retailer sebesar Rp.26,140,220. Hasil yang didapatkan biaya pengiriman metode software lingo lebih murah dengan selisih sebesar Rp.52,899 dibanding metode VAM karena dengan penggunaan Software Lingo terdapat perbedaan alokasi pengiriman dari gudang ke retailer. Pada penelitian ini juga didapatkan hasil biaya pengiriman dari distributor ke gudang sebesar
Rp.25,655,900 sehingga total biaya pengiriman dari distributor ke gudang dan dari gudang ke retailer sebesar Rp.51,796,120.

\section{Kesimpulan:}

Berdasarkan hasil perhitungan menggunakan Lingo Solver Software untuk mendapatkan hasil ongkos minimum untuk memenuhi kebutuhan setiap titik tujuan (retailer) sesuai dengan maksimal kapasitas setiap gudang, didapatkan hasil biaya pengiriman dari distributor ke dua gudang sebesar Rp.25,655,900 dan biaya pengiriman dari gudang ke 36 retailer sebesar Rp.26,140,220 maka biaya total distribusi semen Garuda dari distributor 
ke dua gudang dan dari gudang ke 36 retailer sebesar Rp. 51,796,120. Biaya pengiriman dari gudang ke retailer pada perhitungan model transshhipment dengan menggunakan Lingo software menghasilkan penghematan biaya sebesar Rp. 52,899 dari biaya awal. Pada hasil solver menunjukkan terdapat 4 retailer yaitu Babakan Jaya (R3), TB Ibu 3 (R15), Mega Asri (R18), dan Nensin (R26) yang tidak mendapatkan pasokan semen karena kapasitas gudang yang tidak cukup dan tarif pengiriman per sak yang akan mempengaruhi biaya total distribusi lebih besar dari Rp. $51,796,120$. Perhitungan yang sangat cepat dengan menggunakan solver Lingo ini akan sangat membantu perusahaan dalam menyelesaikan model dengan kendala yang cukup banyak. Efisiensi waktu yang didapatkan dalam pemecahan masalah menggunakan solver Lingo ini perlu diperhatikan oleh perusahaan.

\section{Daftar Pustaka}

Aida, Fitria Noor, and Windi Rahmanda. 2020. "Analisis Biaya Transportasi Distribusi Pupuk Menggunakan Software Lingo." JURNAL REKAYASA SISTEM INDUSTRI 5(2):135. doi: 10.33884/jrsi.v5i2.1930.

Anon. 2011. "Modul 5 Model ITransportasi." Retrieved (https://myteks.wordpress.com/2011/0 3/19/modul-5-model-transportasi/).

Bella, Budiani, Destiani Siti Amelia, and Mulyadi S. Namun. 2020.

"Transshipment Dengan Program Lingo Dalam Distribusi Produk Multivitamin." 1(2):131-42. doi: 10.20473/ajim.v1i1.19171.

Christian, Samuel Arief. 2019. "Peranan Metode Transportasi Dalam Optimasi Biaya Distribusi Semen Garuda CV. Bangun Kreasi Abadi Kota Bandung.” Universitas Kristen Maranatha, Bandung.

Hartono. 2017. “Optimalisasi Biaya
Transportasi Dengan Model Transhipment Dalam Pendistribusian Pupuk Bersubsidi Pada Cv Gilang Perkasa Pasuruan." Universitas Jember.

Margaretta, Friska. 2018. "PenerapanMetode Transportasi Dan Transshipment Menggunakan Program Solver Dalam Efisiensi BiayaDistribusi LPG 3 KG Di PT. Pertamina." Universitas SumateraUtara.

Muhamad, Gumilar Nur. 2020. "Optimalisasi Biaya Distribusi Beras Subsidi Dengan Model Transshipment." Jurnal Teknik Industri: Jurnal Hasil Penelitian Dan Karya Ilmiah Dalam Bidang Teknik Industri 6(1):40. doi: 10.24014/jti.v6i1.9476.

Muhammad, Candra Hadi, Zaenal Abidin, Jurusan Matematika, and Universitas Negeri Semarang. 2013. "Optimalisasi Model Transshipment Di Pt. Primatexco Menggunakan Program Solver." Unnes Journal of Mathematics 2(1):0-5. doi: 10.15294/ujm.v2i1.1713.

Ord, Keith, and H. A. Taha. 2014. Riset Operasi. Vol. 2. edited by B. Aksara. Jakarta.

Ratnasari, Yuli, Desi Yuniarti, and Ika Purnamasari. 2019. "Optimasi Pendistribusian Barang Dengan Menggunakan Vogel's Approximation Method Dan Stepping Stone Method ( Studi Kasus: Pendistribusian Tabung Gas LPG $3 \mathrm{Kg}$ Pada PT . Tri Pribumi Sejati )." Jurnal EKSPONENSIAL $10(2): 165-74$

Silviani, Irine. 2012. “Optimalisasi Distribusi Pupuk Urea Bersubsidi Dl Kabupaten Sumbawa." Universitas Terbuka.

Siswanto. 2006. Research Operation. 1st ed. Jakarta: Erlangga.

Syafi'i, Muhammad Farid. 2015. "Optimalisasi Biaya Transportasi Dalam Pendistribusian Pupuk Bersubsidi Pada CV. Jamantara." Universitas Jember. 